\title{
Transport Infrastructure as a Factor of Economic Growth in Azerbaijan
}

\author{
Maharramov Amil Mammadali ${ }^{*}$, Khasiyev Bahruz Gabil ${ }^{2}$ \\ ${ }^{1}$ Department of "Economics and Management, Baku State University, Azerbaijan \\ ${ }^{2}$ Odlar Yurdu University, Baku, Azerbaijan \\ amagerramov@gmail.com*, khasiyev@gmail.com
}

\begin{abstract}
The nature of the transport infrastructure has been shown as an important factor in the socioeconomic development of its countries. Here, in our country, the developmental possibilities of the transportation system and the basic directions of the state policy towards the development of the transportation infrastructure have been shown. Some aspects of the transport's role in the country's economy have been reviewed. Basic indicators of the development of the transport infrastructure and information on the current state of transport infrastructure for the various countries of the world are provided. Some provisions regarding the effect of the development of transportation infrastructure on the economic growth, the development of the economy are mentioned. A number of expected economic impacts have been shown from investments made to improve the transport infrastructure at the end.
\end{abstract}

Keywords: Transport infrastructure, various of transport, investments in the transport sector, transport system, economic growth

\section{Introduction}

The integration of globalization and international sales markets, geographical mobility of the population and the development of social consumption, has increased its role as an important component in the transport infrastructure in individual regions and in the socio-economic development of all countries. The complementary medium of the transportation production process played an important role in the history of human development, such as the fundamental factor of recycling, and the development of this area has always been closely related to the development of the community. At the same time, transport has a major role in the optimal placement of individual production sites. The development of the productive forces required for the production of material blessings during various periods of the development of the society, various transportation types played an important role in the transport of the produced products. As a result, the transportation system has now become one of the key infrastructure areas that ensure the reliable effectiveness of the national economy and the defense capability of the state. Today, large-scale regional and international projects are being carried out in the Azerbaijan Republic's enterprise, active participation and transport sector. By rapidly integrating the European and Asian transportation systems, the country is transformed into one of the major transport-transit junctions of the Euro-Atlantic space. Saying with the words of the revered President Ilham Aliyev (2015): "Azerbaijan will have an indispensable role in the field of transportation, our geographical situation creates these possibilities, but we are adding infrastructure projects to this geographical situation. Today, transportation infrastructure is the first area for the investments that have been made in Azerbaijan, this is very necessary for our country, we must do it ".

Indeed, transportation has a special place in the development of the economy and is considered to be an important factor in the formation of economic and social space. As a special form of material production, transport affects the demands of the population and the business sector by providing movement of goods and people. Railways, water, automobiles, air and pipelines constitute the only transport system, where passenger and freight volume are the main indicators. In the rise of the economy, it is not just to consider transportation as an area. Transportation is a sophisticated system that improves existing conditions in freight and passenger transport, in the management of the economy, and in people's living activities. The uninterrupted development of transportation is the guarantee of economic perception, liberal change of goods and services, liberation in economic activity, competition and increase of living conditions of the population. The normal operation of the production and exchange process of the goods (products) is also provided with the help of transportation means. 


\section{Literature Review}

According to Hacizade (2014), transportation is one of the basic components of the economic infrastructure, such as the movement of passengers and cargoes, and the material production area, which in this line technological processes are realized. It has a significant impact on economic growth, helping to improve labor productivity, raising the level of living, or reducing the time for people to travel to work, housing, and to any destination in general. Some scientists (Werner Bayer, Rahul A.Sirohi, 2015 ) by infrastructure mean an efficient transportation system, an adequate power generation and distribution system, an efficient telecommunication structure, a modern system of ports and airports, and adequate social infrastructure (water supply, sewage, and waste disposal system). The economic impact of transport infrastructure investment has been explored since the work of Aschauer (1989). Aschauer (1989) estimated the impact of "core" infrastructure (streets, highways, airports, and water systems) on economic growth and productivity in the United States during 1949-1985. The same result was found by Munnell (1990), Lynde \& Richmond (1993), Holtz-Eakin \& Schwartz (1994) and others. Munnell (1990) suggest that infrastructure does contribute towards a state's employment growth. Holtz-Eakin \& Schwartz (1994), who were among the first to incorporate infrastructure in a neoclassical growth model, do not find a very large role for infrastructure in the growth pattern of states. However, they also say that the importance of infrastructure is probably underestimated as they cannot totally control for the endogeneity problem, that is higher productivity gives states more money to invest in infrastructure. In a study about public investment spending and productivity in the United Kingdom, Lynde \& Richmond (1993) conclude that higher infrastructure investments could have brought about an increase in labor productivity in the United Kingdom of about 4 to 4,5\% per year.

Other researchers appraised the "broader" economic effects of transport infrastructure by considering the indirect effects on neighboring geographic areas, attempting to enhance the precision of the effects of infrastructure (Cohen, 2010; Tong et al., 2013). Bağırov (2007) states that if infrastructure is more effectively used by a country, that country will go to a higher steady-state income per capita than a country that does not use infrastructure so effectively. By exploring the role of transport in the country's economy generally there are three ways to approach. First, the establishment of relations between the different regions of the country, the development of the transport system, to assess the availability of resources and production capacity, but also allows to plan economic activity. Second, the development of the transport system and spatial development of the country, where people live, work and draw conclusions about the opportunity to implement measures for their transportation. Third, the management of public transport in the public transport infrastructure investment in developing and influencing the development of the transport system should focus on. There is a functional relationship between transport and economic growth. The development of transport networks, positive relationship, the acceleration of economic growth, such as employment growth, could lead to a reduction in the cost of production and distribution. It is also possible negative effects as well, such as the increase in emissions of pollutants. Evaluating the impact of the economic growth of the country's transport infrastructure, passenger and cargo transportation volume, the length the roads and employment indicators in the field of transportation should be used (Table 1).

Table 1: The main indicators of the development of transport infrastructure

\begin{tabular}{|c|c|c|c|c|c|}
\hline $\begin{array}{l}\text { Criteria in the areas of transport } \\
\text { infrastructure }\end{array}$ & 2011 & 2012 & 2013 & 2014 & 2015 \\
\hline $\begin{array}{l}\text { Transport and non-transport cargo } \\
\text { turnover, million ton-km }\end{array}$ & 95122 & 93869 & 94946 & 97631 & 96846 \\
\hline $\begin{array}{l}\text { Passenger turnover in the transport sector, } \\
\text { million passenger-km }\end{array}$ & 22881 & 25083 & 27307 & 28905 & 30111 \\
\hline $\begin{array}{l}\text { The average annual number of employees, } \\
\text { by thousand }\end{array}$ & 1134 & 1173 & 1223 & 1202 & 1273 \\
\hline The length of roads, $\mathrm{km}$ & 18986 & 18994 & 19002 & 19016 & 19016 \\
\hline The length of railways, km & 2,798 & 2,820 & 2,826 & 2,603 & 2,446 \\
\hline Value-added (current prices), mln & 2,659 & 2,694 & 2,569 & 2,656 & 2,932 \\
\hline
\end{tabular}

Source: Prepared by authors according to the data of the State Statistics Committee 
It is understood from the information given that the volume of passenger and freight transports, the length of transportation routes and the number of the population working in the transport sector are increasing and the volume of value added is also increasing as well.

World experience: In majority of development countries (USA, Germany, Japan) the problems of forming of backbone road network have been solved on the basis of long-term State Programs covering features of development of road network and corresponding volumes of financial provision. So much so that experts have been evaluating the impact of the "Fast Highway Federal System" program on the US economy and the lifestyle of the Americans over the past 100 years. The establishment of a high-speed road system has led to increased business activity, increased volume of investments, increased labor efficiency, increased number of new jobs, and reduced traffic accidents in the United States. In the USA, the increase in labor productivity related to this field is $25 \%$ and the general economic income is 2,1-2,5 trln. dollar. Yet it is 6-19 times of the cost of building these high-speed roads. The first measures in the field of European Union transport policy belong to the formation of the transport structure of Trans Europe and the integration of the new members of the European Union into the general transport network. The European Union allocates considerable financial resources to the priority projects in the development of the motor vehicle network, which is necessary to increase the capacity of the roads. In China, India and Brasilia, the network of high-speed roads is developing. Along with the construction of roads, it is anticipated that local roads will be built to increase the load of the network in these countries and to reduce the return period of investments (Воронцова,2007).

\section{Methodology}

This research depends mainly on statistical data, which was obtained from the State Statistical Committee of the Republic of Azerbaijan for an eight (8) year period, "2007-2014." This period was selected because it is the time during which the observed investment activity in the transport sector.

Table 2: Investments and revenues by various types of transportation (mln. manat)

\begin{tabular}{llllllllll}
\hline \multicolumn{2}{c}{ Type of transportation } & $\mathbf{2 0 0 7}$ & $\mathbf{2 0 0 8}$ & $\mathbf{2 0 0 9}$ & $\mathbf{2 0 1 0}$ & $\mathbf{2 0 1 1}$ & $\mathbf{2 0 1 2}$ & $\mathbf{2 0 1 3}$ & $\mathbf{2 0 1 4}$ \\
\hline Railway & revenues & 178,2 & 205,8 & 149,7 & 158,4 & 196,7 & 223,3 & 236,3 & 232,1 \\
& investment & 4,4 & 13,4 & 2,8 & 3,4 & 3,1 & 5,9 & 4,3 & 1,6 \\
Sea & revenues & 100,3 & 116,1 & 122,5 & 107,2 & 109,7 & 97,9 & 102,3 & 94,0 \\
& investment & 21,2 & 65,6 & 35,6 & 13,2 & 83,5 & 9,7 & 142,6 & 112,7 \\
\multirow{4}{*}{ Air } & revenues & 326,4 & 372,0 & 331,5 & 388,9 & 557,9 & 779,8 & 837,8 & 828,1 \\
\multirow{2}{*}{ Pipeline } & investment & 83,0 & 99,8 & 31,9 & 214,1 & 180,5 & 282,0 & 82,2 & 397,2 \\
\multirow{2}{*}{ Automobile } & revenues & 1157,9 & 1393,9 & 1705,5 & 1712,6 & 1605,9 & 1448,9 & 1439,1 & 1679,8 \\
& investment & 23,5 & 27,2 & 21,9 & 344,8 & 253,5 & 218,3 & 53,7 & 313,9 \\
& revenues & 331,9 & 426,8 & 569,1 & 669,9 & 784,6 & 916,0 & 1020,0 & 1128,7 \\
& investment & 167,4 & 173,7 & 156,4 & 162,9 & 228,0 & 453,1 & 358,2 & 237,6 \\
\hline
\end{tabular}

With the increase in transport infrastructure, the time spent moving and transporting in transport decreases, the volume of transactions increases, and this is reflected in the increase in revenues.

\section{Conclusion}

As can be seen in the table 2, a large amount of pre-established investments increase revenues and continue to generate income in an increasingly small amount. Although the main revenues are obtained on the pipeline, the raw material orientation of Azerbaijan is obvious. Considering that about $50 \%$ of the income of Azerbaijan's state budget is made up of oil-exporting, of course, the pipeline plays an important role in the development of the Azerbaijani economy, depending on the higher income of this type of transportation. It is pleasant that, if we do not consider pipelines in transportation, automobile transportation is the leading place. This means that Azerbaijan is using the transit more and more from the possibilities of international transport. Investments made in large quantities of automobile loans in 2012-2013 give their own results today. In 2014, despite the decrease in investments in automobile loans, revenues have increased to account for investments made in advance. The main reason for the increase is that in recent years the implementation of privatization policies on these types of vehicles has resulted in an increase in the number of new national 
transportation companies, an increase in the level of equipment through automobile transportation in the transport parcels, and a rise in freight and passenger flows as a result of the creation of new production and infrastructure areas for Baku and regions.

Practically, investment in transport infrastructure is directly linked to economic growth. Investments in transportation infrastructure are practically regarded as an incentive for economic growth. They contribute to the economic development of regions, towns and villages. They reduce transport costs, reduce the level of regional economic disparity, increase exit competition to new markets, increase labor movements, and reduce the cost of cargo transshipments within the framework of foreign and domestic logistics systems. All of this leads to increased labor productivity and new competitive advantages. As a rule, these can be expressed as follows:

- Improving quality characteristics as a result of investments in high-speed motorways, airports, modern railways for high-speed trains;

- Effective use of existing power;

- Optimization of the transportation process with the use of intelligent system etc.

Such changes have a positive effect on the overall level of the mentioned transport services and ultimately economic growth. The construction of transportation networks allows citizens to move around the country. The current road scarcity slows down the process of adaptation of the socio-economic development level of the regions. Improvement of the transportation infrastructure and every factor influencing the formation and development of the transportation service market leads to a decrease in the cargo price and the expansion of access to various commodity markets. Increased export opportunities lead to increased production, increased sales, restructuring of companies' production lines, the formation of new logistics companies, and reduced production costs. Reducing transportation costs leads to widening of the labor market, making markets more accessible.

Recommendations: Such an economic effect can be seen by investing in investment projects:

- As new roads are constructed and restructured, the moving distance will be reduced, the driving time of the drivers will be optimized, the high quality route will be spent less time at the same distance and there will be a saving opportunity for the costs of the entities;

- The increase in the quality of automobile roads will create new routes by sharing the transportation between the vehicles. This will encourage the efficient use of modern logistics technologies;

- The development of the transportation infrastructure will lead to the optimal placement of the productive forces, productive forces, efficient use of natural resources, commodity markets and service expansion;

Thus, nearly developed transport infrastructure will contribute to the infrastructure capital increase, to the reduction of the final price of goods, to the increase in the volume of transports, to the efficient use of business power, and to the entrance of companies into new markets. In its turn, efficient use of workforce will cause employment and income per person to increase at a high rate. The emergence of new markets and transportation networks, innovations and technology, will increase trade expansion and ultimately increase overall labor productivity. Together, this will bring real GDP per capita to grow.

\section{References}

Aschauer, D. A. (1989). Is public expenditure productive? Journal of Monetary Economics, 23, 177-200.

Bağırov, F.(2007). Ölkənin sosial-iqtisadi inkişafında nəqliyyatın rolunun yüksəldilməsi istiqamətləri. Journal of Naqliyyat hüququ, 3(12), 26-33

Cohen, J. (2010). The Broader Effects of Transportation Infrastructure: Spatial Econometrics and Productivity Approaches. Transportation Research Part E, 46(3), 317-326.

Hacızadə, E. M. (2014). Regional nəqliyyat infrastrukturunun təkmilləşdirilməsində Baki-Tbilisi-Qars dəmir yolu xətti layihəsinin rolu. Journal of Azarbaycan Vergi jurnall, 3(117), 123-160 


\section{Journal of Social and Development Sciences (ISSN 2221-1152)}

Vol. 8, No. 3, pp. 35-39, September 2017

Holtz-Eakin, D. \& Schwartz, A. E. (1994). Infrastructure in a structural model of economic growth o. Document Number)

Lynde, C. \& Richmond, J. (1993). Public capital and long-run costs in U.K. manufacturing. The Economic Journal, 103(419), 880-893.

Munnell, A. H. (1990) How does public infrastructure affect regional economic performance? New England Economic Review, Sept/Okt.

Tong, T., Yu, T. E., Cho, S., Jensen, K. \& de la Torre Ugarte, D. (2013). Evaluating the Spatial Spillover Effect of Transportation Infrastructure on Agricultural Output Across the United States. Journal of Transport Geography, 30, 47-55.

Воронцова, С. (2007). Дороги- гарант экономической стабильности. Journal of “Российское Экспертное обозрение" №1. [internet resource] http://www.protown.ru/information/articles/3339.html

http://az.trend.az/business/economy/2460629.html

http://www.stat.gov.az/. 